\title{
COPYCAT FUNDS: INFORMATION DISCLOSURE REGULATION AND THE RETURNS TO ACTIVE MANAGEMENT IN THE MUTUAL FUND INDUSTRY
}

\author{
Mary Margaret Myers \\ James M. Poterba \\ Douglas A. Shackelford \\ John B. Shoven \\ Working Paper 8653 \\ http://www.nber.org/papers/w8653 \\ NATIONAL BUREAU OF ECONOMIC RESEARCH \\ 1050 Massachusetts Avenue \\ Cambridge, MA 02138 \\ December 2001
}

We are grateful to Dan Bergstresser, Joel Dickson, Jennifer Wilson, seminar participants at the University of Illinois-Chicago and Indiana University, and especially Mark Wolfson for helpful discussions. We also thank Jennifer Blouin, V.J. Bustos, Rachel Ferguson, Michael Myers, Angel Townsend, and Candice Whitehurst for excellent research assistance, the Ernst \& Young Foundation, the National Science Foundation (Poterba) and the University of Chicago (Myers) for research support, and John Rekenthaler and Annette Larson at Morningstar for providing mutual fund data. The views expressed herein are those of the authors and not necessarily those of the National Bureau of Economic Research.

(C) 2001 by Mary Margaret Myers, James M. Poterba, Douglas A. Shackelford and John B. Shoven. All rights reserved. Short sections of text, not to exceed two paragraphs, may be quoted without explicit permission provided that full credit, including (C) notice, is given to the source. 
Copycat Funds: Information Disclosure Regulation and the Returns to

Active Management in the Mutual Fund Industry

Mary Margaret Myers, James M. Poterba, Douglas A. Shackelford and John B. Shoven

NBER Working Paper No. 8653

December 2001

JEL No. G28, G23, K22, L15

\begin{abstract}
Mutual funds must disclose their portfolio holdings to investors semiannually. The costs and benefits of such disclosures are a long-standing subject of debate. For actively managed funds, one cost of disclosure is a potential reduction in the private benefits from research on asset values. Disclosure provides public access to information on the assets that the fund manager views as undervalued. This paper tries to quantify this potential cost of disclosure by testing whether "copycat" mutual funds, funds that purchase the same assets as actively-managed funds as soon as those asset holdings are disclosed, can earn returns that are similar to those of the actively-managed funds. Copycat funds do not incur the research expenses associated with the actively-managed funds that they are mimicking, but they miss the opportunity to invest in assets that managers identify as positive return opportunities between disclosure dates. Our results for a limited sample of high expense funds in the 1990s suggest that while returns before expenses are significantly higher for the underlying actively managed funds relative to the copycat funds, after expenses copycat funds earn statistically indistinguishable, and possibly higher, returns than the underlying actively managed funds. These findings contribute to the policy debate on the optimal level and frequency of fund disclosure.
\end{abstract}

Mary Margaret Myers

Graduate School of Business

University of Chicago

1101 East 58th Street

Chicago, IL 60637

Douglas A. Shackelford

Kenan-Flagler Business School

University of North Carolina

Campus Box 3490, McColl Building

Chapel Hill, NC 27599-3490

and NBER
James M. Poterba

Department of Economics

Massachusetts Institute of Technology

50 Memorial Drive

Cambridge, MA 02142-1347

and NBER

poterba@mit.edu

John B. Shoven

Department of Economics

Stanford University

Encina Hall

Stanford, CA 94305

and NBER 
The U.S. Securities and Exchange Commission is currently considering modifying the regulations that govern disclosures that mutual funds must make to their shareholders. Under the 1940 Investment Company Act, investment companies must disclose both their performance and their current portfolio holdings in semi-annual reports to shareholders. These reports must be sent to the shareholders no more than sixty days after the reporting period ends. A number of organizations representing fund shareholders have called for more frequent disclosure of mutual fund holdings, on the grounds that they would enable investors to more accurately select funds that match their investment objectives. More frequent disclosure would presumably permit shareholders to detect, sooner, changes in fund investment strategy. They would consequently reduce the risk that fund managers could pursue investment strategies that do not coincide with their shareholders' wishes.

Previous research on financial disclosure recognizes that mandatory disclosure has both costs and benefits. The costs include the direct expenses associated with producing and disseminating information on investment positions, as well as a range of potential costs that a discloser may face when private information becomes publicly available. The benefits of disclosure emanate from improved monitoring of fund managers, and from potential improvements in investor choice that result from detailed information availability. Both the costs and benefits of disclosure are typically very difficult to quantify.

In the mutual fund context, Wermers (2001) notes that there are two potential costs to the investors in a fund when the fund is required to disclose its holdings. First, when a fund discloses its holdings, it becomes easier for other investors to use information on fund inflows to "front-run" the fund's trades, thereby bidding up the prices of the securities that the fund manager wishes to buy. This cost is presumably greater when disclosure is more frequent, and it translates into a lower return on the fund's investments. Second, disclosure reduces the time period over which fund investors are able to reap the private rewards of their manager's securities research. The managers who direct investments in activelymanaged open-end mutual funds carry out research about various securities to identify underpriced assets that will generate above-average, risk-adjusted returns. Because disclosure reveals the identity of the securities that the fund manager has purchased, it reduces the potential returns to a manager's research. 
Potential competitors, as well as fund shareholders, learn about a fund manager's investments when the fund discloses its holdings. The fund manager's unique return to investing in the securities that his research suggests are under-valued is therefore limited to the time between the completion of the research, and the next disclosure date. This analysis presumes that research by fund managers uncovers positive return opportunities; a large empirical literature, reviewed for example in Gruber (1996), suggests that this assumption is open to debate.

These two costs must be balanced against the potential benefits of disclosure both from the standpoint of an individual fund manager who is considering increasing the frequency of disclosure, and from the standpoint of a regulator trying to design an optimal policy. One potential benefit of disclosure may be heightened demand for the securities owned by a disclosing fund. If other investors decide to purchase the securities that a fund already owns because they believe that the disclosing manager has private information, this may drive up the price of these securities, thereby raising the returns on the fund that makes the disclosure.

Another benefit is that some investors may attach substantial value to frequent disclosure, and therefore be prepared to accept higher fees or lower returns to receive frequent fund disclosures. Frequent disclosure makes it difficult for funds to pursue strategies that are substantially different from the ones that they advertise. The gains from such disclosure depend on the likelihood that funds change their strategies without informing their shareholders, and on the cost to shareholders of deviations from preannounced strategies. Although the current regulatory environment requires semi-annual disclosure, some managers voluntarily disclose their fund positions more frequently than the SEC requires. They presumably believe that investors are more likely to invest in a fund that provides timely portfolio information, and they value the associated increase in their fund's assets more highly than the potential future inflows associated with higher current returns.

The possibility that some firms may voluntarily disclose more than the regulators require, to attract a particular investor clientele is not unique to the mutual fund market. In discussing insider trading regulation, Manne (1966) argued that even if insiders were not legally prevented from trading in their 
firm's shares, some firms would voluntarily choose to prohibit such transactions. they would thereby attract investors who were prepared to accept slow incorporation of information into prices (if insiders could not trade) in return for excluding better-informed traders from the market.

A third potential benefit of disclosure is that it may convey information on a firm's successful past investments to prospective investors and thereby attract them to the fund. Verrecchia (1983) notes that voluntary disclosures of product innovations or other research results may increase firm value by persuading investors of the firm's research acumen. This can occur even though disclosure facilitates the competitive strategies of rivals and reduces the market value of the proprietary returns on the research being disclosed. The literature on "window dressing" by mutual funds and other investment managers, including Carhart, Kaniel, Musto, and Kadlec (2000), Lakonishok, Shleifer, Thaler, and Vishny (1991), and O'Neal (2001), suggests that managers believe that investors will judge prospective performance on the basis of past performance.

The problem of deciding how to regulate information flows between a mutual fund and its current and prospective investors is closely related to a range of problems in financial accounting regulation. For example, regulators and managers have long debated the extent to which requiring geographic segment disclosures, and other types of detailed financial information release, conveys valuable information to a firm's competitors without providing much information to investors. A number of previous studies have considered the design of disclosure regulation for financial information. Foster (1980) notes that the "externalities" associated with financial reporting may lead firms to under-provide information in an unregulated market. Admati and Pfleiderer (2000) investigate the nature of voluntary disclosure equilibria, and the circumstances under which disclosure regulation is welfare-enhancing. Both of these studies note that the optimal regulatory structure for disclosure will depend on the firm-specific costs of disclosing information.

Optimal disclosure policy depends on the costs and benefits of disclosure, yet there is remarkably little empirical evidence on either of these issues. This paper seeks to provide new insight on one of the potential costs of information disclosure in the actively-managed mutual fund industry, namely the 
reduction in potential excess returns earned by the managers of actively-managed equity funds. We emphasize that this is only one of the potential costs of disclosure, and that an improved measure of this cost alone does not resolve the question of the optimal degree of disclosure, which must depend on the costs as well as benefits of potential disclosure rules.

To investigate how disclosure affects the returns earned by actively-managed mutual funds and other investors, we create "copycat" funds that allocate assets to match the latest publicly-disclosed holdings of actively-managed funds. We then compare the returns of each copycat fund with the returns of the mutual fund that it mimics. If research is valuable in uncovering positive return opportunities, the copycat fund should earn lower returns than its primitive actively-managed fund. The active manager can implement the results of new research immediately, while the copycat manager can only trade on new information after it is publicly disclosed. The copycat fund's potential disadvantage in timely access to research findings may be offset, however, by the fact that the copycat fund also has virtually no research expenses. Thus, it is possible that a copycat fund and an actively managed fund could deliver similar net of expense returns, even if the copycat fund earns a lower return before expenses.

We recognize that our tests are of greatest interest when research by active managers has the potential to generate positive returns before fund expenses. If active managers are unable to add value through their research, copycat funds should be able to match the returns of their primitive funds before expenses, and they should offer superior returns net of expenses.

Our research strives to provide insight on the extent to which expense savings can compensate for foregone asset allocation opportunities on the part of copycat funds. We investigate the viability of the copycat strategy by studying the returns to a set of actively-managed funds and associated copycat funds from 1992-1999. The view that disclosure restricts the capacity of actively-managed funds to reap the potential benefits of their research findings would be consistent with the net-of-expense returns to copycat funds proving indistinguishable from the returns of primitive funds, while the before-expense returns of the primitive funds exceed those of the copycats. 
Our analysis is divided into five sections. Section one summarizes the disclosure regulations that currently apply to mutual funds and provides background for understanding our copycat fund strategy. Section two describes our algorithm for managing a copycat fund, including the frequency of portfolio adjustments and the relationship between the dates when actively-managed funds disclose information and the dates when copycat funds rebalance their holdings. Section three explains the selection process for the actively managed funds in our data sample and presents summary statistics on the expenses and returns on these funds. Section four reports our principal empirical findings. In most cases, we find that returns to the primitive funds exceed those of the copycat funds before expenses. When we compute returns to both the primitive and the copycat funds net of expenses, however, returns on the copycat funds often exceed those on the primitive funds, although we typically cannot reject the null hypothesis that returns on the copycat funds are equal to those of the primitive funds. A brief conclusion outlines several broad issues related to information disclosure by financial intermediaries that emerge from our analysis.

\section{Disclosure Regulations and the Mutual Fund Industry}

Mutual funds are required to disclose semiannually their balance sheets, including a list of the securities that they hold and the value of these securities. Section 30(e) of the Investment Company Act of 1940 stipulates the relevant disclosure requirements, and specifies that the list of securities held must be for a "reasonably current date." Securities and Exchange Commission Rule 30b1-1 is more specific in outlining the process of disclosure. Registered investment companies must file form N-SAR not more than 60 calendar days after the close of their fiscal year, and again after the close of the second quarter of their fiscal year.

Fund families vary in their disclosure policies. Some, such as funds in the Fidelity family, do not make voluntary disclosures. Most funds, however, disclose their holdings before the end of the twomonth grace period, and many funds disclose portfolio holdings on a quarterly basis. For example, the Vanguard Group discloses its funds' holdings every quarter with a one-month lag. In addition, monthly disclosures, which were rare five years ago, are now common. The Wall Street Journal (April 30, 1999) 
reports that 30 percent of mutual funds, including the Janus and USAA Investment Management fund families, release complete portfolio holdings monthly to Morningstar, a firm that tracks returns and provides investors with information that they may find useful in evaluating mutual funds. The fact that investors pay substantial sums to Morningstar to obtain these data suggests that at least some market participants regard fund disclosures as valuable information, perhaps because it offers a guide to the future behavior of fund managers. Some firms even disclose more frequently than monthly. Laderman (1999) reports that the Open Fund posts all of its trades and reports its entire portfolio in real time on its web site.

Fund families that do not voluntarily disclose their holdings typically cite distribution costs as the major impediment to more frequent disclosures. For instance, the Omni Investment Fund historically mailed monthly statements of fund holdings to its small group of shareholders. Fairley (1997) reports that after Berger Associates fund family acquired Omni, disclosures were reduced to semiannual reports because of distribution costs. However, even when funds do not mail detailed disclosures to all investors, some funds will provide a complete list of their investments, or a partial listing with their most significant holdings, to investors. Investors also may obtain information that is not mailed to all shareholders by contacting the fund manager directly. Fund web sites increasingly disseminate additional portfolio information.

\section{Primitive and Copycat Funds}

To evaluate one of the costs of information disclosure for actively-managed equity funds, we design "copycat funds" that spend nothing on research but select assets by following an actively-managed fund. The fund that carries out research on asset selection is the primitive fund. Let the return on this

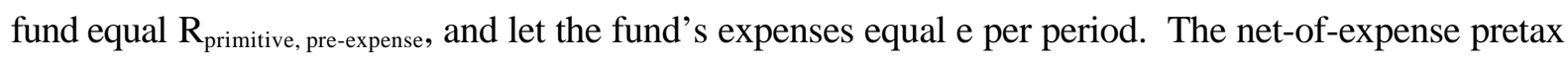
return to an investor in this fund is

$$
\mathrm{R}_{\text {primitive, net }}=\mathrm{R}_{\text {primitive, pre-expense }}-\mathrm{e} \text {. }
$$


When detailed information on the primitive fund's portfolio holdings become available, the copycat fund will align its portfolio exactly with the reported holdings of the primitive fund. Consistent with the SEC mandatory disclosure rules, the primitive fund is assumed to disclose exactly sixty days after the close of the primitive fund's second and fourth quarters of the fiscal year. This assumption implies that the copycat fund is always at least two months "out of date" in tracking the primitive fund. It can be as much as eight months behind the primitive fund, in the days immediately prior to a new semiannual disclosure.

The manager of the actively-managed fund changes asset allocation between the dates of required disclosure, while the copycat fund only adjusts its portfolio when the manager of the actively-managed fund discloses new holdings. If identification of new stocks by actively-managed funds generates a uniform distribution of trades between disclosure dates, the manager of the primitive fund will hold a security for five months, on average, before the copycat fund will purchase it. This lag may be longer if the active manager pursues strategies designed to prevent imitation, such as delaying the purchase (sale) of some securities that may have positive (negative) return possibilities until just after the disclosure date. If the active manager is completely successful in camouflaging his or her fund's true portfolio holdings, then the copycat fund will not even be able to hold a lagged version of the actively-managed fund's portfolio. In this case, the copycat fund will be holding a portfolio that corresponds to whatever assets the actively managed fund found it attractive to purchase as part of the camouflage program.

The extent to which managers at actively managed funds trade to disguise their holdings at the time of disclosure is an open issue. While masking strategies can avoid informing competitors and investors about current portfolio positions, they may also impose potentially substantial transaction costs on the fund pursuing them. Musto (1999) discusses more generally the potential gains from short-term trading that is designed to affect the information transmitted to investors, and O'Neal (2000) presents some evidence of fund return abnormalities around fund disclosure dates, suggesting that some unusual trading may take place. 
We denote the before-expense return on the copycat fund as $\mathrm{R}_{\text {copycat, pre-expense. If the stock }}$ selection associated with active management generates positive returns, we would expect that

$$
\mathrm{R}_{\text {copycat, pre-expense }}<\mathrm{R}_{\text {primitive, pre-expense. }}
$$

The copycat fund is always relying on dated information in making portfolio choices, so its returns should be lower than those of the actively managed fund that takes full advantage of new information as it arrives. However, the critical question for investors is whether the copycat fund's return, net of expenses, exceeds the comparable return on the primitive fund. If a fraction $\lambda$ of the actively-managed fund's expenses is associated with research and other costs of active management, such as brokerage fees, then the copycat fund can generate an after-expense return of

$$
\mathrm{R}_{\text {copycat, net }}=\mathrm{R}_{\text {copycat, pre-expense }}-(1-\lambda) \mathrm{e} \text {. }
$$

The parameter $\lambda$ is likely to vary across funds of different types. Our analysis focuses on pretax returns, but we note that for taxable investors, the capital gains tax liability associated with investments in copycat funds might be lower than those for primitive funds, since the copycat funds will presumably trade less than the primitive fund. Because the copycat fund only trades twice each year, to realign its portfolio and that of the primitive fund, it is somewhat less likely than the primitive fund to realize capital gains.

Our empirical work computes the differential return of the primitive and copycat funds on a preexpense and a post-expense basis, and tests for statistically significant values of

$$
\Delta_{\text {pre-expense }}=R_{\text {primitive, pre-expense }}-R_{\text {copycat, pre-expense }}
$$

and

$$
\Delta_{\text {net }} \quad=\mathrm{R}_{\text {primitive, net }}-\mathrm{R}_{\text {copycat, net }} \text {. }
$$

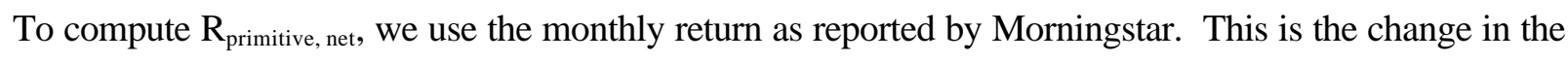
fund's net asset value (NAV) during the month divided by the net asset value at the beginning of the month, assuming reinvestment of dividends and capital gains distributions. NAV equals the fund's total assets, less fees and expenses, divided by the number of shares outstanding. This return is net of expenses paid from fund assets, such as 12b-1 and management and administrative fees. 
Our primitive fund return is not reduced for loads, brokerage costs, and other costs that do not easily convert to monthly returns. To the extent that actively-managed primitive funds are burdened more than passive copycats with these additional costs, $\mathrm{R}_{\text {primitive, net }}$ understates the potential net return advantages of copycat funds. In the empirical tests, $R_{\text {primitive, pre-expense }}$ equals $R_{\text {primitive, net }}$ plus an estimate of the monthly expenses paid from fund assets. The estimated monthly expense is $1 / 12$ of the percentage of the fund's assets deducted each fiscal year for fund expenses. For example, assume that Morningstar reports a return of 2.0 percent for a fund in a given month, and that the fund's annual expense ratio is 1.2 percent. In this case, the estimated monthly expense ratio is 0.1 percent, 1.2 percent/12, and the adjusted monthly return is 2.1 percent $(2.0+0.1)$.

We compute the copycat's pre-expense return, $\mathrm{R}_{\text {copycat, pre-expense, }}$ as the sum of the value-weighted monthly returns for each stock held by the primitive fund. Portfolio holdings and their weights are collected from Morningstar. The monthly returns for stocks are computed by compounding daily returns in the daily CRSP files. If the stock is listed on CRSP, we use its daily returns including distributions. If a common stock is not listed on CRSP, for example if it is a closely-held or foreign-controlled company, we assume its daily return equals the distribution-inclusive return on the value-weighted market portfolio as reported in the CRSP files. If a common stock held by the copycat fund drops from CRSP during the six-month buy and hold period between information disclosures we assume that the assets previously held in that stock earn the value-weighted market return until the next disclosure of information from the primitive fund. This is tantamount to assuming that the copycat fund manager reinvests, in a broad market index, the proceeds from selling shares that stop trading.

Many of the primitive funds in our sample hold some of their assets in securities other than corporate stocks that are included on the CRSP tape. Computing the returns on these other assets is problematic because we often lack detailed information on the identity of the asset, the return on the asset, or both. To overcome these problems, we make a range of assumptions with respect to copycat fund returns. First, we assume that bonds earn the Ibbotson Associates monthly return on long-term corporate bonds. Second, we assume that cash earns the Treasury bill monthly rate. Third, we assume that the 
returns on small equity and other asset holdings are proportional to the return on the fund's other assets. Morningstar rounds the portfolio percentage weight to zero if the fund holds less than 0.006 percent of its portfolio in a specific security. Only about one percent of the equities held by funds in our sample have weights below this threshold, and the median fund in both samples had no holdings below this threshold. ${ }^{1}$ We assume that the assets in this unreported category are invested in the other assets in the copycat fund (i.e., equities, bonds and cash), with weights equal to the share of the other assets in the copycat fund's portfolio. Finally, we assume that preferred stock that is not listed on the CRSP files also earns the average return of the copycat fund's other assets. We do this because preferred stock has both equity and bond features.

To illustrate our procedure for constructing copycat fund returns, suppose a fund's assets are invested 40 percent in Common Stock A, which is included in the CRSP files, 25 percent in Common Stock B, which is not listed in CRSP, 30 percent in Bond C, and 4.98 percent in cash. The remaining 0.02 percent of the portfolio is invested in four stocks, each comprising 0.005 percent of the portfolio. First, we drop the four stocks that comprise only 0.005 percent of the fund, because Morningstar reports their portfolio weights as 0 percent, and reweight the remaining investments. Stock A's weight is now assumed to be $40.008\{40 /(100-0.02)\}$ percent, B's weight is 25.005 percent, C's weight is 30.006 percent, and the cash weight is now 4.981 percent. If Stock A has a 4 percent return for the period, the market return is 3 percent, the Ibbotson Associates return on long-term corporate bonds is 2 percent, and the Treasury bill rate is 1 percent, then the copycat return is 3 percent $(.03=(40.008 * 0.04+25.005 * 0.03$ $+30.006 * 0.02+4.981 * 0.01) / 100)$.

At least one possible measurement problem arises with this computation method. Morningstar does not necessarily simultaneously report equity portfolio weights and the overall asset allocation from which we set bonds and cash weights. Thus, if information is released on different dates, our computation of total weights may not equal 100 percent. We therefore reweight the holdings to achieve a consistent

\footnotetext{
${ }^{1}$ The maximum percentage of assets in holdings below this threshold is 16.4 percent in Sample 1 , and 21.9 percent in Sample 2.
} 
outcome. For example, suppose Morningstar releases equity portfolio weights that disaggregate 95 percent of a fund's equity holdings at year-end, while also reporting that the fund's overall asset allocation is 97 percent equity and 3 percent bonds for the month prior to the year-end. The portfolio weights would be adjusted by the ratio $100 /(95+3)$, leaving the total equity holdings at 96.9 percent (95/98) and the bond holdings at 3.1 percent (3/98) of the fund. In practice, there are no more than sixteen days, on average, between the dates of portfolio and asset allocation disclosure, so we suspect that the inconsistencies associated with the differential dating are limited. Further, the average difference between the sum of the portfolio equity weights and the reported allocation to equities is only one percent.

The SEC allows funds sixty days following the end of the period to disclose their holdings. We therefore begin estimating returns to the copycat fund two months after the end of the reporting period. For example, a mutual fund with a calendar year-end must disclose its year-end portfolio holdings by the end of February. It must make a similar report on its holdings late in the second quarter by the end of August. Therefore, the copycat fund returns for the March - August period use the primitive fund's portfolio holdings reported at the end of February, and copycat fund returns for September - February use the primitive fund's disclosure from late August. The estimated copycat fund returns for each of these periods are then compared with the primitive fund's returns for the same period. Our assumption that the copycat fund can only track the primitive fund's portfolio from the semiannual mandatory disclosure is conservative because if the primitive fund makes voluntary disclosures, the copycat fund can track its asset holdings more closely. We assume that the expenses incurred by copycat funds equal the expenses of the Vanguard Total Stock Index fund. This is an index fund that invests in both large and small capitalization stocks, and we view its expenses as illustrative of the costs a passively-managed copycat fund might incur. We will demonstrate below that our qualitative findings with respect to the performance differentials between primitive and copycat funds are relatively insensitive to modest changes in our assumptions about the expenses of copycat funds.

We report monthly return differentials, $\Delta_{\text {pre-expense }}$ and $\Delta_{\text {net }}$, for each of the six months between the disclosure dates of the primitive fund. Because the copycat fund's portfolio holdings should stray more 
from the primitive fund's holdings as the time since the last disclosure increases, there may be some information in the patterns of return differentials for different months. We also report cumulative return differentials for the one to six month intervals between these disclosures.

\section{Data Sample and Fund Selection}

The potential net return advantage of a copycat fund is greatest for a primitive fund that has a high expense ratio. Such funds might be, but are not necessarily, engaged in more research than other funds. If one were going to introduce a copycat fund into the mutual fund marketplace, it would be natural to use a high expense fund as a primitive, since its high expenses would offer the greatest promise for the copycat, through it's low-cost strategy, to outperform. For this reason, we begin our empirical analysis by examining a sample of large equity funds with high expenses. To assess the robustness of our findings, we repeat the analysis on a broader sample of funds. We focus on equity funds because it is relatively easy, using the CRSP tapes, to track the return on these funds' investments. In practice, there is no reason a copycat fund needs to be concerned about the availability of CRSP data. The copycat strategy could easily be applied to funds that hold more exotic assets, provided the information disclosed by the primitive fund made it possible for the copycat manager to identify the underlying assets in the primitive fund's portfolio.

We draw our sample from the equity mutual funds included on Morningstar's July 1992 Principia database. Because CRSP only reports returns for equity securities on domestic stock exchanges, we eliminate international equity funds. We also exclude small capitalization funds and specialty funds from our sample; these could be the subject of separate, follow-on studies. Our sample restrictions limit our sample universe to 812 funds. We draw two samples of funds from this universe. ${ }^{2}$

The High-Expense Fund Sample. The first sample comprises the 20 funds that appear to meet most closely the definition of large, diversified equity funds with large investor fees. The sample

\footnotetext{
${ }^{2}$ We supplemented our initial sample, which was collected by hand from 1992-93 Morningstar reports, with a database supplied by Morningstar, Inc. for 1993-1999.
} 
excludes funds that invest in assets other than equities and cash. Furthermore, the cash allocation must be less than 10 percent of all investments. We exclude funds with sales charges equal to zero and expense ratios less than 1 percent. The sample also excludes index funds, funds with assets of less than \$200 million, and funds with more than half their assets allocated to equities in one industry. For these 20 mutual funds, we collected data from Morningstar for all of the SEC-mandated semiannual reporting periods between 1992 and 1999. ${ }^{3}$ Since our data set spans just over six years, disclosures occur twice each year, and we have twenty funds, we would have a maximum of roughly $240(=20 * 6 * 2)$ observations on fund disclosure. In fact, we have a somewhat smaller sample -- 188 disclosures. We have not addressed issues concerning survivorship biases for the funds in our sample, since we are not comparing returns for these funds with other funds or the broad market, but rather with a set of hypothetical copycat funds that are tracking the funds in our sample.

The Broader Equity Fund Sample. Our second sample is larger and is drawn with fewer restrictions. It includes the largest 100 funds (by net asset value) that allocate less than forty percent of their assets to bonds, preferred stock or convertible securities. As with the previous sample, index funds are excluded, and the data come from the SEC-mandated semiannual reports for 1992 -1999, available through Morningstar. Appendix A lists the set of funds for both the high-expense fund sample and the broader equity fund sample. We define an observation for the purpose of our sample size as a fund disclosure.

Table 1 provides descriptive statistics for the two fund samples. On average, equities tracked by CRSP comprise 91 (81) percent of the high-expense (broader) sample's portfolios. For the median funds in each sample, the analogous statistics are 92 percent and 86 percent, respectively. Some funds in each sample have more than 100 percent of their assets in equity; this reflects levered equity positions.

\footnotetext{
${ }^{3}$ The earliest possible reporting period-end for this sample is January 31, 1992, so the six-month buy and hold copycat calculations commence April 1, 1992. The latest possible reporting period-end for this sample is April 30, 1999, so the six-month buy and hold copycat calculations end on December 31, 1999. This sample cutoff implies that 1999 only has 3 funds for sample 1 and 23 funds for sample 2. The final sample does not necessarily reflect all of the restrictive screens in every period. If a fund met the restrictions in July 1992, it was included in the sample even if at other times during 1992 - 1999 it did not meet the restrictions.
} 
Average turnover is similar, at 85 and 81 percent, respectively, in the two samples. Funds in the high expense sample have annual expenses that average 1.4 percent of NAV, versus 0.9 percent for the broader fund sample. On average, the higher expense ratio funds are smaller than those in the broader sample, hold slightly smaller companies, and employ newer portfolio managers. The funds in the high expense ratio sample have a slightly longer period between disclosures of portfolio holdings and asset allocation. The average number of disclosures to Morningstar over the previous twelve months, and the average difference between the sum of the portfolio equity weights and the reported allocation to equities, are similar for the two samples.

\section{Empirical Findings}

In this section, we report our results on the relative returns on copycat funds and on their primitive actively-managed funds. We begin by reporting our findings for the sample of high-expense funds, and we then move on to the broader sample of equity funds. We conclude by reporting the results of a regression analysis of the factors that explain the differential between copycat and primitive returns.

\subsection{Results for the Sample of High Expense Ratio Funds}

Table 2 summarizes our findings on relative returns on funds in the high expense ratio group and their copycats. Panel A reports mean and median returns in each of the six months between one disclosure date and the next, while panel B presents cumulative results for periods of between one and six months. The first and second rows present summary statistics on returns for both primitive and copycat funds, while the third and fourth rows present return differentials between the two sets of funds. Row three considers return differentials before expenses, while row four considers the differential net of expenses.

The mean primitive return is greater than the mean copycat fund return in all but one of the six months. However, only in month 6 is the return differential significant at the .05 level using a two-tailed test. (We use two-tailed tests throughout the paper.) Neither the absolute nor the median monthly return difference ever exceeds 20 basis points. Mean differences remain fairly constant over the six months. 
Consistent with deterioration in the copycats' ability to track their underlying primitive funds, the difference between the copycat and the primitive fund returns increases over time. ${ }^{4}$ The standard deviation of the monthly differences between the primitive and the copycat return, while not shown in the table, averages 80 basis points in the first three months after the information disclosure and rises to 110 basis points in the last three months. The average absolute monthly return differences (also not reported) also increase from 50 basis points in month 1 to 80 basis points in month 6. Similarly, the correlation between actual and copycat returns declines slightly during the six months. The correlation coefficient for the two returns averages 0.98 during the first three months after the information disclosure and 0.96 during the next three months.

When both the primitive and copycat fund returns are adjusted for their estimated monthly expenses, the copycat funds outperform the primitive funds in four of the six months. However, the spread remains insignificantly different from zero except in month 4. The absolute values of the mean return differences remain at or below 20 basis points. $^{5}$

Panel A in Table 2 presents returns for individual months between portfolio disclosures by primitive funds. Panel B translates these monthly returns into cumulative buy-and-hold returns. Descriptive statistics are provided for returns over one- through six-month holding periods. The key question that these results can address concerns the statistical significance of the cumulative return differential between the primitive and copycat funds. The table shows that the difference between the primitive and copycat fund returns at the end of the six-month holding period, net of expenses, is not significantly different from zero. The mean difference at the end of six months on the before-expense return is 42 basis points, and this differential is statistically significantly different from zero. Thus the primitive funds earn a higher return than the copycats. On a net-of-expense basis, however, the copycat

\footnotetext{
${ }^{4}$ In future work we plan to develop more sophisticated measures of the relative riskiness of the primitive and copycat funds, including both the variance of returns and the covariance between the returns and the market portfolio.

${ }^{5}$ The results are robust to the assumptions about the returns generated by non-equity investments. We computed returns to primitive and copycat funds under different assumptions about the returns to non-equity assets, such as
} 
fund return exceeds the primitive fund return by an average of 24 basis points, and we cannot reject the null hypothesis that the two cumulative returns are equal. The differences between the primitive and the copycat fund returns grow larger as the return horizon is lengthened. The only statistically significant difference in cumulative returns before expenses occurs six months after the information disclosure. ${ }^{6}$

The results from the high expense ratio sample indicate that a copycat fund can track a primitive fund closely for up to six months following portfolio disclosures. Return differences between the copycat and the associated primitive fund are statistically insignificant regardless of whether we deduct none of the primitive fund's expenses, or all of these expenses, from its returns. This indicates that our findings are unaffected by choices of $\lambda$, the fraction of the fund's expenses that are attributable to research expenses, in equation (3) above. If we included the tax costs that taxable investors face as a result of turnover by actively managed funds, the net-of-expense return advantage for copycat funds would become even larger.

\subsection{Results for the Broader Sample of Equity Funds}

Table 3 presents both individual month returns and cumulative returns for the 847 observations in our broader sample of actively-managed funds. Our findings from the high expense ratio sample carry over to the broader sample as well. Table 3 shows that when we ignore expenses, primitive funds outperform their associated copycat funds in five of the six months between disclosure episodes. (The return reversal occurs in the third month after the disclosure, when we estimate the average return on the copycat funds to be greater than that on the primitive funds.) The difference in monthly returns, however, is never statistically significantly different from zero, and it is never substantively very large. When fund expenses are deducted from the returns of both the primitive and copycat funds, the mean difference in

zero return and assuming that all non-equity assets earned the equity index return. These assumptions did not affect our basic finding that copycat returns and primitive fund returns are not statistically significantly different. ${ }^{6}$ To address the potential problems associated with asynchronous reporting of portfolio weights and the overall allocation to equities, we repeated our analysis excluding the one percent of funds with the largest differences between their portfolio weights for equities and their overall asset allocation to equities. For the remaining 179 observations in the high expense sample, the absolute difference was less than or equal to eight percentage points, which gives us greater confidence that the copycat fund's asset allocation mimics the underlying mutual fund's. The conclusions from Panels A and B of Table 2 are not affected by this sample restriction. 
the monthly returns is negative for five of six months, but the difference is statistically significant only in month three. The copycat funds generate higher net-of-expense returns in all months, except the sixth month, between disclosure dates.

The cumulative returns in the lower panel of Table 3 show that before expenses, the returns to holding primitive rather than copycat funds are very similar. After six months, there is only a thirteen basis point difference, on average, between the two sets of returns, and this difference is not statistically significantly different from zero. When we compute the difference in returns net of expenses, however, the average return on the copycat funds is higher than the average return on the primitive funds, and we can reject the null hypothesis that this differential is zero. Most of the differential return in favor of the copycat funds emerges in the first four months after the information disclosure. ${ }^{7}$ After six months, the cumulative return differential is 25 basis points in favor of the copycat funds.

The evidence for the broader sample of funds provides stronger support for the view that copycat funds can outperform their primitive funds, net of expenses, than the comparable results for the sample of high expense ratio funds. This appears to be due to the greater sample size, and correspondingly smaller standard errors, in the broader fund sample. The cumulative return differential between the primitive and the copycat funds, net of expenses, is similar in the two samples.

\subsection{Investigating the Source of Return Differences}

The summary statistics in Tables 2 and 3 offer insight on the viability of copycat funds as a competitive alternative to their primitive funds, but they do not provide any insight on the factors that contribute to larger or smaller return differentials. To explore this issue, we relate the cumulative return differential before expenses to a small set of characteristics of the primitive fund. These characteristics, while chosen in a somewhat arbitrary fashion, are designed to capture both factors that might mechanically lead to differences between the copycat and primitive fund return, as well as factors that might make it more difficult for the copycat to track the primitive fund.

\footnotetext{
${ }^{7} \mathrm{We}$ also repeated this analysis on a subsample of funds that measure asset allocation more precisely, and again our conclusions did not change.
} 
Table 4 presents the results of ordinary least squares regressions in this spirit. While the analysis is not motivated by a tightly-specified model of return differentials, the findings should provide some guidance for future model development. The dependent variable for the regressions in the first column of Table 4 is the pre-expense six-month cumulative return differential. The estimates in the upper panel correspond to the high-expense fund sample, while those in the lower panel apply to the broader sample. The explanatory variables include the percentage of stocks that we were able to find on the CRSP return tapes, turnover, the primitive fund's expense ratio, its total asset value, the capitalization of the companies that the fund holds, dummy variables for each year, and a variable capturing the manager's tenure.

In both the high-expense and broader fund samples, we find that the difference in pre-expense returns between the primitive fund and the copycat is decreasing in the percentage of fund assets invested in equities covered by CRSP. This result indicates that when the copycat fund is able to positively identify a higher fraction of the primitive fund's assets, the copycat fund's return is closer to that of the primitive fund. Greater identifiability decreases the ability of a primitive fund manager to earn superior returns. Most of the other variables that we include in the regression model have a statistically insignificant effect on the return differential between primitive and copycat funds.

The second column of Table 4 presents the results of estimating models in which the dependent variable is the absolute value of the pre-expense return differential between the primitive and the copycat fund. In this case, we again find that the share of the portfolio that consisted of CRSP-identifiable equities is negatively associated with this measure of the variation between the primitive and the copycat fund. The effect is statistically significant in both the high-expense sample and in the broader sample, but it is much larger in the high expense sample. There are also other statistically significant covariates in this case. We find, for example, that the absolute value of the return differential is increasing in the primitive fund's turnover rate. Copycat funds on average track the primitive fund returns less well when the primitive funds exhibit high turnover. This makes sense; the copycat fund manager is chasing a "faster moving target" when the primitive fund has a higher turnover rate. We also find, in the broader 
sample, that higher expense ratios for the primitive funds are associated with larger absolute return differentials between the primitive and the copycat funds, before expenses.

The results in this section are strictly descriptive. Nevertheless, they provide some guidance on the potential efficacy of copycat funds in tracking the returns of actively managed equity funds. We do not find any large differences between the returns of the primitive funds and the copycat funds in our sample, and we uncover plausible patterns in the type of actively-managed funds that copycats are likely to have the most success in tracking.

\section{Conclusions}

In this paper, we construct hypothetical "copycat" funds that will mimic the portfolio of the associated "primitive" fund each time the primitive fund discloses its portfolio holdings. We find that for a broad sample of diversified U.S. equity mutual funds over the 1992-1999 period, the average returns before expenses on the copycat funds are lower than the corresponding returns on the primitive funds. Whether we can reject the null hypothesis that the two sets of returns have the same mean is sensitive to our choice of sample with respect to primitive funds. We reject the equality of before-expense returns in a sample of high expense ratio funds, while we do not reject this equality for a broader sample of funds. However, the returns net of expenses, which are the returns available to investors in mutual funds, are higher on the copycat funds than on the primitive funds. This is true for both samples of funds, although we only reject the null hypothesis of equal returns for the broad sample of funds. The disparity between the net-of-expense returns on the copycat and primitive funds clearly depends on the assumption that we make about the expenses associated with managing a copycat fund. We assume that these expenses would be comparable to the expenses of current index funds; if the expenses were actually larger, the corresponding return differential would be smaller.

Our findings suggest that copycat funds have the potential to generate returns that are roughly comparable to the returns on the primitive funds that they are designed to mimic. This suggests that one of the costs associated with financial disclosures, namely the prospect of competitors trading on the 
information that such disclosure reveals about the primitive fund's portfolio, may be substantial. We have not tried to explain why investors hold actively managed equity funds, and we have not contributed to the debate on whether actively-managed funds, or copycat funds based on these funds, can outperform broad market benchmarks. These are large issues that go well beyond the current paper. However, we have shown that whatever benefit investors in actively managed funds think that they receive from these investments, in terms of subsequent returns, can be imitated to a substantial degree by copycat funds.

Our analysis considers only one of the potential costs of financial disclosure, and it does not attempt to quantify any of the potential benefits associated with disclosure. As such, it cannot be construed as providing ultimate guidance on the design of disclosure regulations, although it might be an input to the regulatory process.

Two features of our study design may lead us to overstate the return on the copycat fund, relative to the primitive fund. Both reflect our analysis of hypothetical copycat funds, rather than copycat funds that actually operate in the market and that primitive funds recognize and respond to.

First, if the security purchases by the copycat fund drive up the prices of securities already held by the primitive fund, then the primitive fund is in a sense "front running" purchases by the copycat fund. This could increase the returns on the primitive fund, particularly in the first month after portfolio holdings are disclosed. There is some evidence that front-running of stock purchases by mutual funds can generate substantial returns. Gasparino (1997) reports that the Vanguard Group stopped reporting information about the net cash flows into its funds because third parties were apparently using this information to "front run" Vanguard funds. If a potential investor knew the largest holdings of a given Vanguard fund, and he also knew that the fund had experienced a large cash inflow, he might be able to identify securities for which there would be substantial demand in the near future. Fidelity, which once released daily information on the size of some of its sector funds, has similarly stopped reporting this information because it may be of use to investors who are trying to profit from the fund's prospective purchases. We are not aware of any evidence that quantifies the potential returns to front-running. 
Second, if copycat funds were an important feature of the mutual fund landscape, activelymanaged funds might take actions that would reduce the information content of their semiannual disclosures. This is analogous to the problem, described in Lerner (1995), that faces a firm that plans to patent a new technology, when the details revealed in the patent application will provide valuable insights to potential competitors.

If the managers of primitive funds could camouflage their actual portfolio holdings, this would potentially increase the return differential between the primitive and the copycat funds. If actively managed funds do earn positive returns as a result of their information, it would presumably raise the return on the primitive funds relative to that of the copycats. There is no consensus at present on the extent to which mutual fund managers engage in "window dressing," or changing the composition of their portfolios near the end of a reporting period. The attractiveness of window dressing depends on the transaction costs associated with moving in and out of a particular security, including any costs of execution associated with the bid-ask spread. Such a trading strategy might make sense for large companies whose shares are actively traded in liquid markets. For smaller and less liquid securities, we suspect that the transaction costs would outweigh the gain from dissembling from competitors. Musto (1999) finds evidence of window dressing among money market fund managers. The potential benefits from security selection in the equity markets probably exceeds the comparable benefits in the short-term money market; this suggests that window dressing may also exist in the equity fund market, as O'Neal (2001) suggests.

While these two considerations may lead us to understate the return advantage of the primitive fund, one other factor is likely to operate in the reverse direction. This is our assumption that the copycat only obtains information about the primitive fund's holdings every six months. In practice, we know that many actively managed funds reveal information more often than this, and presumably a copycat fund trying to mimic such a fund would be able to track the primitive's return performance more closely.

The issues that we have discussed with respect to mutual funds also arise in a variety of other contexts where imitation can reduce the value of initial research investments. Tax shelters provide one 
example. Sullivan (1999) writes that "tax shelters cannot be copyrighted. Eventually, the word gets out to other clients, to competitors, and even to the IRS. It is hard to justify large fees for tax shelters that many firms market ..." One way that law and accounting firms that design tax shelters attempt to reduce this diffusion of information is by asking potential clients to sign confidentiality agreements before they learn about the details of a potential shelter. These agreements presumably slow, but do not prevent, the ultimate diffusion of information.

Our analysis of one potential cost of information disclosure, and our discussion of other potential costs, bears on only one side of the balance that must ultimately be used to determine optimal regultaory policy with respect to information disclosure. The most important need for policy design in this area is information on the potential benefits that investors receive from information disclosure. This presumably requires information on the likelihood that fund managers will change their investment objectives without informing shareholders, and on the level of disclosure that would take place if there were no regulatory requirements for disclosure. 


\section{REFERENCES}

Admati, Anat and Paul Pfleiderer (2000), "Forcing Firms to Talk: Financial Disclosure Regulation and Externalities," Review of Financial Studies 13, 479-519.

Carhart, Mark, Ron Kaniel, David Musto, and Adam Reed (2001), "Leaning for the Tape: Evidence of Gaming Behavior in Equity Mutual Funds," Journal of Finance (forthcoming).

Fairley, Juliette (1997), “Keeping More Under Their Hats,” New York Times (June 15), p. F7.

Foster, George (1980), "Externalities and Financial Reporting," Journal of Finance 35, 521-533.

Freeman, John P. and Stewart L. Brown (2001). "Mutual Fund Advisory Fees: The Cost of Conflicts of Interest," Journal of Corporation Law 26 (3), 610-673.

Gasparino, Charles (1997). "Vanguard's Cutback of Fund Data May Mean It Fears a Market Drop," Wall Street Journal (October 14).

Gigler, Frank (1994), “Self-enforcing Voluntary Disclosures,” Journal of Accounting Research 32:2, 224240.

Gruber, Martin J. (1996), "Another Puzzle: The Growth of Actively-Managed Mutual Funds," Journal of Finance 51, 783-810.

Laderman, Jeffrey M. (1999), “A Mutual Fund That Lets It All Hang Out,” Business Week (September 27), p. 126.

Lakonishok, Josef, Andrei Shleifer, Richard Thaler, and Robert Vishny (1991), "Window Dressing by Pension Fund Managers," American Economic Review 81 (May), 227-231.

Lerner, Josh (1995), "Patenting in the Shadow of Competitors," Journal of Law and Economics 38 (2), 463-495.

Manne, Henry G. (1966). Insider Trading and the Stock Market. (New York: The Free Press).

Musto, David K. (1999), "Investment Decisions Depend on Portfolio Disclosures," Journal of Finance 54 (June), 935-952.

O'Neal, Edward (2001), "Window Dressing and Equity Mutual Funds," mimeo, Babcock Graduate School of Management, Wake Forest University.

Sullivan, Martin (1999), “One Shelter at a Time?,” Tax Notes (December 6), 1226-1229.

Verrecchia, Robert. (1983), “Discretionary Disclosure,” Journal of Accounting and Economics, 5, 179194.

Wermers, Russ (2001), "The Potential Effects of More Frequent Portfolio Disclosure on Mutual Fund Performance," Investment Company Institute Perspective 7 (June). 
Table 1: Summary Statistics for Samples Using Information from Mandatory Disclosure Periods (1/92-4/99)

\begin{tabular}{|c|c|c|c|c|c|c|}
\hline & Mean & Minimum & $1 \%$ & Median & $99 \%$ & Maximum \\
\hline \multicolumn{7}{|c|}{ High Expense Ratio Funds $(N=188)$} \\
\hline Share of Holdings in Equity & $\begin{array}{c}0.93 \\
(0.08)\end{array}$ & 0.06 & 0.62 & 0.94 & 1.02 & 1.14 \\
\hline Share of Holdings in CRSP Stock & $\begin{array}{c}0.91 \\
(0.09)\end{array}$ & 0.06 & 0.62 & 0.92 & 1.00 & 1.14 \\
\hline Share of Holdings in Private Equity & $\begin{array}{l}0.00 \\
(.01) \\
\end{array}$ & 0 & 0 & 0 & 0.03 & 0.07 \\
\hline Share of Holdings in Foreign Stock & $\begin{array}{c}0.06 \\
(0.11)\end{array}$ & 0 & 0 & 0.02 & 0.82 & 0.94 \\
\hline Share of Holdings in Unknown & $\begin{array}{c}0.00 \\
(0.00) \\
\end{array}$ & 0 & 0 & 0 & 0.02 & 0.02 \\
\hline Turnover (annual) & $\begin{array}{c}0.85 \\
(0.63)\end{array}$ & 0 & 0 & 0.70 & 3.19 & 3.19 \\
\hline Expense Ratio & $\begin{array}{c}0.014 \\
(0.004)\end{array}$ & 0.006 & 0.006 & 0.013 & 0.024 & 0.024 \\
\hline Asset Value $(\$ B)$ & $\begin{array}{c}2.16 \\
(3.48)\end{array}$ & 0.15 & 0.16 & 0.52 & 17.05 & 21.41 \\
\hline $\begin{array}{l}\text { Median Market Capitalization, } \\
\text { Stocks Held }(\$ B)\end{array}$ & $\begin{array}{c}10.20 \\
(10.59)\end{array}$ & 0.43 & 0.72 & 7.17 & 65.10 & 76.18 \\
\hline Manager's Tenure (years) & $\begin{array}{c}6 \\
(4.78)\end{array}$ & $\overline{0}$ & $\overline{0}$ & 5 & 24 & 24 \\
\hline $\begin{array}{l}\text { Number of Disclosures Over } \\
\text { Prior Twelve Months }\end{array}$ & $\begin{array}{c}2.05 \\
(1.41)\end{array}$ & 0 & 0 & 2 & 8 & 9 \\
\hline $\begin{array}{l}\text { Number of Days Between Current } \\
\text { and Prior Disclosure }\end{array}$ & $\begin{array}{l}159.12 \\
(68.25) \\
\end{array}$ & 29 & 30 & 182 & 547 & 547 \\
\hline
\end{tabular}


Table 1 (continued): Summary Statistics for Samples Using Information from Mandatory Disclosure Periods (1/92-4/99)

\begin{tabular}{|c|c|c|c|c|c|c|}
\hline & $\begin{array}{l}\text { Mean } \\
(\mathrm{STD}) \\
\end{array}$ & Minimum & $1 \%$ & Median & $99 \%$ & Maximum \\
\hline \multicolumn{7}{|c|}{ Broader Sample of Funds $(N=847)$} \\
\hline Share of Holdings in Equity & $\begin{array}{c}0.84 \\
(0.14)\end{array}$ & 0.16 & 0.41 & 0.89 & 1.00 & 1.05 \\
\hline Share of Holdings in CRSP Stock & $\begin{array}{l}0.81 \\
(.15) \\
\end{array}$ & 0.16 & 0.37 & 0.86 & 0.99 & 1.03 \\
\hline Share of Holdings in Private Equity & $\begin{array}{c}0.001 \\
(0.008)\end{array}$ & 0 & 0 & 0 & 0.031 & 0.168 \\
\hline Share of Holdings in Foreign Stock & $\begin{array}{c}0.129 \\
(0.264)\end{array}$ & 0 & 0 & 0.026 & 1.30 & 0.124 \\
\hline Share of Holdings in Unknown & $\begin{array}{c}0.000 \\
(0.002)\end{array}$ & 0 & 0 & 0 & 0.011 & 0.039 \\
\hline Turnover (annual) & $\begin{array}{c}0.81 \\
(0.64)\end{array}$ & 0 & 0.10 & 0.62 & 2.97 & 3.74 \\
\hline Expense Ratio & $\begin{array}{l}0.009 \\
(.003)\end{array}$ & 0.001 & .001 & 0.009 & 0.019 & 0.023 \\
\hline Asset Value (\$B) & $\begin{array}{c}6.36 \\
(8.99)\end{array}$ & 0.25 & .69 & 3.38 & 49.23 & 90.78 \\
\hline $\begin{array}{l}\text { Median Market Capitalization, } \\
\text { Stocks Held }(\$ B)\end{array}$ & $\begin{array}{c}12.70 \\
(12.33) \\
\end{array}$ & 0.24 & 0.66 & 9.09 & 61.63 & 91.19 \\
\hline Manager's Tenure (years) & $\begin{array}{c}8.27 \\
(7.90)\end{array}$ & 0 & 0.13 & 6.00 & 37.78 & 40.78 \\
\hline $\begin{array}{l}\text { Number of Disclosures Over } \\
\text { Prior Twelve Months }\end{array}$ & $\begin{array}{c}2.49 \\
(1.72) \\
\end{array}$ & 0 & 0 & 2 & 9 & 11 \\
\hline $\begin{array}{l}\text { Number of Days Between Current } \\
\text { and Prior Disclosure }\end{array}$ & $\begin{array}{l}144.25 \\
(86.16)\end{array}$ & 28 & 30 & 181 & 366 & 1277 \\
\hline $\begin{array}{l}\text { Number of Days Between Portfolio } \\
\text { and Allocation Disclosure }\end{array}$ & $\begin{array}{c}7.62 \\
(15.99) \\
\end{array}$ & 0 & 0 & 0 & 90 & 92 \\
\hline $\begin{array}{l}\text { Sum of Portfolio Equity Weights } \\
\text { Less Reported Allocation to Equities }\end{array}$ & $\begin{array}{c}0.01 \\
(0.04)\end{array}$ & -0.23 & -0.08 & 0.00 & 0.09 & 0.79 \\
\hline
\end{tabular}

Source: Authors' calculations using data collected from Morningstar database. 
Table 2

Monthly Returns on Primitive Funds and Copycat Funds, High-Expense Ratio Sample

\begin{tabular}{|l|c|c|c|c|c|c|c|}
\hline & Month 1 & \multicolumn{2}{l|}{ Month 2 } & \multicolumn{1}{l|}{ Month 3 } & \multicolumn{2}{l|}{ Month 4 } & \multicolumn{2}{l|}{ Month 5 } & Month 6 \\
\hline Panel A: Individual Month Returns for Mandatory Disclosure Periods from 1/1992-4/1999 & \\
\hline Primitive Fund Returns, Before & 1.55 & 1.13 & 1.51 & 2.00 & 1.52 & 1.01 \\
Expenses & $(4.25)$ & $(4.19)$ & $(3.89)$ & $(3.61)$ & $(3.83)$ & $(4.64)$ \\
& {$[1.88]$} & {$[1.50]$} & {$[1.61]$} & {$[2.19]$} & {$[1.46]$} & {$[1.38]$} \\
\hline Copycat Fund Returns, Before & 1.50 & 1.09 & 1.46 & 2.08 & 1.40 & 0.82 \\
Expenses & $(4.28)$ & $(4.13)$ & $(3.85)$ & $(3.61)$ & $(3.63)$ & $(4.50)$ \\
& {$[1.77]$} & {$[1.73]$} & {$[1.37]$} & {$[2.18]$} & {$[1.45]$} & {$[1.22]$} \\
\hline Primitive Return Less Copycat & 0.05 & 0.05 & 0.06 & -0.08 & 0.12 & 0.19 \\
Return, Before Expenses & {$[-0.02]$} & {$[0.05]$} & {$[-0.00]$} & {$[-0.08]$} & {$[0.08]$} & {$[0.15]$} \\
(Full Sample, N = 188) & $\{0.84\}$ & $\{0.83\}$ & $\{0.85\}$ & $\{-1.10\}$ & $\{1.59\}$ & $\{2.52\}$ \\
\hline Primitive Return Less Copycat & -0.06 & -0.06 & -0.05 & -0.19 & 0.02 & 0.09 \\
Return, Net of Expenses & {$[-0.13]$} & {$[-0.03]$} & {$[-0.08]$} & {$[-0.18]$} & {$[-0.04]$} & {$[0.04]$} \\
(Full Sample, N = 188) & $\{-1.03\}$ & $\{-1.03\}$ & $\{-0.74\}$ & $\{-2.46\}$ & $\{0.27\}$ & $\{1.18\}$ \\
\hline Panel B: Buy and Hold Returns for Mandatory Disclosure Periods from 1/1992- $4 / 1999$ & \\
\hline Primitive Fund Returns, & 1.55 & 2.70 & 4.22 & 6.30 & 7.91 & 8.94 \\
Before Expenses & $(4.25)$ & $(5.98)$ & $(6.90)$ & $(8.08)$ & $(9.13)$ & $(9.78)$ \\
& {$[1.88]$} & {$[2.63]$} & {$[4.18]$} & {$[5.40]$} & {$[6.90]$} & {$[8.12]$} \\
\hline Copycat Fund Returns, Before & 1.50 & 2.60 & 4.06 & 6.22 & 7.68 & 8.52 \\
Expenses & $(4.28)$ & $(5.96)$ & $(6.80)$ & $(7.90)$ & $(8.67)$ & $(9.38)$ \\
& {$[1.77]$} & {$[2.52]$} & {$[3.83]$} & {$[5.29]$} & {$[7.47]$} & {$[7.50]$} \\
\hline Primitive Return Less Copycat & 0.05 & 0.09 & 0.15 & 0.08 & 0.22 & 0.42 \\
Return, Before Expenses & {$[-0.02]$} & {$[-0.00]$} & {$[0.03]$} & {$[-0.09]$} & {$[-0.15]$} & {$[-0.03]$} \\
(Full Sample, N = 188) & $\{0.84\}$ & $\{1.12\}$ & $\{1.44\}$ & $\{0.56\}$ & $\{1.29\}$ & $\{2.00\}$ \\
\hline Primitive Return Less Copycat & -0.06 & -0.11 & -0.16 & -0.35 & -0.32 & -0.24 \\
Return, Net of Expenses & {$[-0.13]$} & {$[-0.21]$} & {$[-0.26]$} & {$[-0.43]$} & {$[-0.68]$} & {$[-0.73]$} \\
(Full Sample, N = 188) & $\{-1.03\}$ & $\{-1.37\}$ & $\{-1.52\}$ & $\{-2.58\}$ & $\{-1.91\}$ & $\{-1.13\}$ \\
\hline
\end{tabular}

Notes: Each entry shows the value for the mean return or return differential indicated in the row heading. Standard errors are shown in parentheses, medians are shown in square brackets, and t-statistics for testing the null hypothesis that the relevant mean equals zero are shown in \{\} . See the text for further description of the data sample. 
Table 3

Monthly Returns on Primitive Funds and Copycat Funds, Broader Sample

\begin{tabular}{|c|c|c|c|c|c|c|}
\hline & Month 1 & Month 2 & Month 3 & Month 4 & Month 5 & Montl \\
\hline \multicolumn{7}{|c|}{ Panel A: Individual Month Returns for Mandatory Disclosure Periods from 1/1992- 4/1999 } \\
\hline $\begin{array}{l}\text { Primitive Fund Returns, Before } \\
\text { Expenses }\end{array}$ & $\begin{array}{c}1.72 \\
(3.70) \\
{[2.05]}\end{array}$ & $\begin{array}{l}1.36 \\
(3.88) \\
{[1.62]}\end{array}$ & $\begin{array}{l}1.55 \\
(3.99) \\
{[1.88]}\end{array}$ & $\begin{array}{l}1.71 \\
(3.29) \\
{[1.78]}\end{array}$ & $\begin{array}{c}1.54 \\
(3.68) \\
{[1.80]}\end{array}$ & $\begin{array}{c}0.90 \\
(4.61) \\
{[1.40]}\end{array}$ \\
\hline eturns, Before & $\begin{array}{l}1.71 \\
(3.71) \\
{[1.87]}\end{array}$ & $\begin{array}{c}1.34 \\
(3.79) \\
{[1.53]}\end{array}$ & & & & \\
\hline $\begin{array}{l}\text { Return Less Copycat } \\
\text { Before Expenses } \\
\text { nple, } \mathrm{N}=847 \text { ) }\end{array}$ & $\begin{array}{c}0.02 \\
{[0.05]} \\
\{0.61\}\end{array}$ & $\begin{array}{c}0.01 \\
{[0.04]} \\
\{0.47\}\end{array}$ & $\begin{array}{l}-0.05 \\
{[-0.02]} \\
\{-1.42\}\end{array}$ & $\begin{array}{c}0.02 \\
{[0.09]} \\
\{0.43\}\end{array}$ & $\begin{array}{c}0.05 \\
{[0.03]} \\
\{1.49\}\end{array}$ & $\begin{array}{c}0.08 \\
{[0.08]} \\
\{2.14\}\end{array}$ \\
\hline $\begin{array}{l}\text { Primitive Return Less Copycat } \\
\text { Return, Net of Expenses } \\
\text { (Full Sample, N=847) }\end{array}$ & $\begin{array}{c}-0.04 \\
{[-0.01]} \\
\{-1.64\}\end{array}$ & $\begin{array}{l}-0.05 \\
{[-0.01]} \\
\{-1.43\}\end{array}$ & $\begin{array}{l}-0.11 \\
{[-0.08]} \\
\{-3.18\}\end{array}$ & $\begin{array}{c}-0.04 \\
{[0.03]} \\
\{-1.17\}\end{array}$ & & \\
\hline \multicolumn{7}{|c|}{ Panel B: Buy and Hold Returns for Mandatory Disclosure Periods from 1/1992- 4/1999 } \\
\hline $\begin{array}{l}\text { Primitive Fund Returns, } \\
\text { Before Expenses }\end{array}$ & $\begin{array}{c}1.72 \\
(3.70) \\
{[2.05]}\end{array}$ & $\begin{array}{c}3.10 \\
(5.39) \\
{[2.82]}\end{array}$ & $\begin{array}{l}4.67 \\
(6.51) \\
{[4.79]}\end{array}$ & $\begin{array}{c}6.47 \\
(7.72) \\
{[6.22]}\end{array}$ & $\begin{array}{l}8.09 \\
(8.52) \\
{[7.60]}\end{array}$ & $\begin{array}{l}8.99 \\
(9.07) \\
{[9.33]}\end{array}$ \\
\hline Fund Returns, Before & $\begin{array}{c}1.71 \\
(3.71) \\
{[1.87]} \\
\end{array}$ & $\begin{array}{c}3.07 \\
(5.38) \\
{[2.63]} \\
\end{array}$ & $\begin{array}{c}4.69 \\
(6.47) \\
{[4.64]} \\
\end{array}$ & $\begin{array}{c}6.47 \\
(7.69) \\
{[5.88]}\end{array}$ & $\begin{array}{l}8.04 \\
(8.46) \\
{[7.45]}\end{array}$ & $\begin{array}{c}8.86 \\
(8.91) \\
{[8.50]} \\
\end{array}$ \\
\hline $\begin{array}{l}\text { Primitive Return Less Copycat } \\
\text { Return, Before Expenses } \\
\text { (Full Sample, } \mathrm{N}=847 \text { ) }\end{array}$ & $\begin{array}{c}0.02 \\
{[0.05]} \\
\{0.61\}\end{array}$ & $\begin{array}{c}0.03 \\
{[0.07]} \\
\{0.67\}\end{array}$ & $\begin{array}{l}-0.02 \\
{[0.02]} \\
\{-0.34\}\end{array}$ & $\begin{array}{c}-0.00 \\
{[0.08]} \\
\{-0.05\} \\
\end{array}$ & $\begin{array}{c}0.05 \\
{[0.13]} \\
\{0.57\}\end{array}$ & $\begin{array}{c}0.13 \\
{[0.16]} \\
\{1.34\} \\
\end{array}$ \\
\hline $\begin{array}{l}\text { Primitive Return Less Copycat } \\
\text { Return, Net of Expenses } \\
\text { (Full Sample, } \mathrm{N}=847 \text { ) }\end{array}$ & $\begin{array}{c}-0.04 \\
{[-0.01]} \\
\{-1.64\}\end{array}$ & $\begin{array}{l}-0.09 \\
{[-0.04]} \\
\{-2.02\}\end{array}$ & $\begin{array}{c}-0.20 \\
{[-0.13]} \\
\{-3.40\}\end{array}$ & $\begin{array}{c}-0.25 \\
{[-0.17]} \\
\{-3.12\}\end{array}$ & $\begin{array}{c}-0.26 \\
{[-0.14]} \\
\{-2.84\}\end{array}$ & $\begin{array}{c}-0.25 \\
{[-0.19]} \\
\{-2.49\} \\
\end{array}$ \\
\hline
\end{tabular}

Notes: Each entry shows the value for the mean return or return differential indicated in the row heading. Standard errors are shown in parentheses, medians are shown in square brackets, and t-statistics for testing the null hypothesis that the relevant mean equals zero are shown in \{\} . See the text for further description of the data sample. 
Table 4: Regression Results Explaining Difference in 6-Month Buy and Hold Returns Between Primitive and Copycat Funds

\begin{tabular}{|c|c|c|}
\hline Explanatory Variable & $\begin{array}{l}\text { Primitive Fund Returns } \\
\text { Before Expenses Less } \\
\text { Copycat Returns }\end{array}$ & $\begin{array}{c}\text { Absolute Value of (Primitive Fund } \\
\text { Returns Before Expenses Less } \\
\text { Copycat Returns) }\end{array}$ \\
\hline \multicolumn{3}{|c|}{ High Expense Ratio Sample for Mandatory Reporting Periods $(\mathbf{N}=188)$} \\
\hline Intercept & $\begin{array}{c}0.0748 \\
(0.0270)\end{array}$ & $\begin{array}{l}0.0813 \\
(0.0186)\end{array}$ \\
\hline CRSP Stock & $\begin{array}{c}-0.0753 \\
(0.0240)\end{array}$ & $\begin{array}{c}-0.0706 \\
(0.0166)\end{array}$ \\
\hline Turnover & $\begin{array}{c}0.0061 \\
(0.0038)\end{array}$ & $\begin{array}{c}0.0067 \\
(0.0026)\end{array}$ \\
\hline Expense & $\begin{array}{c}5.6449 \\
(7.0098) \\
\end{array}$ & $\begin{array}{c}6.1708 \\
(4.8394) \\
\end{array}$ \\
\hline Asset Value & $\begin{array}{c}0.0000 \\
(0.0000)\end{array}$ & $\begin{array}{l}-0.0000 \\
(0.0000)\end{array}$ \\
\hline Cap & $\begin{array}{l}-0.0001 \\
(0.0002)\end{array}$ & $\begin{array}{l}-0.0003 \\
(0.0002)\end{array}$ \\
\hline Manager's Tenure & $\begin{array}{c}0.0006 \\
(0.0005)\end{array}$ & $\begin{array}{c}0.0002 \\
(0.0003)\end{array}$ \\
\hline Adjusted $R^{2}$ & 0.10 & 0.20 \\
\hline \multicolumn{3}{|c|}{ Broader Sample for Mandatory Reporting Periods $(\mathrm{N}=847)$} \\
\hline Intercept & $\begin{array}{c}0.0449 \\
(0.0072)\end{array}$ & $\begin{array}{l}0.0198 \\
(0.0051)\end{array}$ \\
\hline CRSP Stock & $\begin{array}{c}-0.0314 \\
(0.0067)\end{array}$ & $\begin{array}{c}-0.0099 \\
(0.0048)\end{array}$ \\
\hline Turnover & $\begin{array}{c}-0.0005 \\
(0.0015)\end{array}$ & $\begin{array}{c}0.0095 \\
(0.0011)\end{array}$ \\
\hline Expense & $\begin{array}{r}-5.8282 \\
(3.6907)\end{array}$ & $\begin{array}{c}8.7557 \\
(2.6150)\end{array}$ \\
\hline Asset Value & $\begin{array}{l}-0.0000 \\
(0.0000)\end{array}$ & $\begin{array}{l}-0.0000 \\
(0.0000)\end{array}$ \\
\hline Cap & $\begin{array}{c}0.0002 \\
(0.0001) \\
\end{array}$ & $\begin{array}{c}-0.0004 \\
(0.0001)\end{array}$ \\
\hline Manager's Tenure & $\begin{array}{l}-0.0002 \\
(0.0001)\end{array}$ & $\begin{array}{c}0.0002 \\
(0.0001)\end{array}$ \\
\hline Adjusted $R^{2}$ & 0.07 & 0.20 \\
\hline
\end{tabular}

Note: Each entry includes the coefficient estimate. Standard errors are shown in parentheses. Bolded entries are those for which we reject the null hypothesis at the coefficient is equal to zero at the $\mathbf{9 5 \%}$ confidence level. See text for further discussion of the regression specification. 


\section{Appendix A: List of Mutual Funds Examined in this Study}

\section{Sample 1}

AAL Capital Growth AIM Constellation AIM Weingarten

Alliance Quasar A American Cap. Pace Fidelity Blue Chip Growth Fidelity Growth Company

Ivy Growth

Kemper Investment Growth Keystone Custodian S-3
Keystone Custodian S-4

Merrill Lynch Fd. Tomorrow B Merrill Lynch Strat. Div. B MFS Lifetime Capital Growth MFS Lifetime Managed Sectors Paine Webber Dividend Grth A Pasadena Growth Pilgrim MagnaCap Prudential Growth B Security Equity 


\section{Sample 2}

$20^{\text {th }}$ Century Growth Inv.

$20^{\text {th }}$ Century Select Inv.

Affiliated

AIM Charter

AIM Constellation

AIM Weingarten

Alliance A

American Cap. Comstock

American Cap. Pace

American Mutual

Brandywine

Capital Income Builder

Common Sense Growth

Delaware Decatur Income

Delaware DelCap Concept I

Dreyfus

Elfun Trusts

Evergreen Total Return

Fidelity

Fidelity Asset Manager

Fidelity Contrafund

Fidelity Destiny I

Fidelity Equity-Income

Fidelity-Income II

Fidelity Growth Company

Fidelity Growth \& Income

Fidelity Magellan

Fidelity Puritan

Fidelity Retirement Growth

Fidelity Trend

Financial Industrial Income

Fundamental Investors

General Electric S \& S Program

Growth Fund if America

IDS Growth

IDS Managed Retirement

IDS Mutual

IDS New Dimensions

IDS Stock

Janus

Janus Twenty

Kemper Growth

Kemper Total Return

Keystone Custodial K-1

Keystone Custodial K-1
Legg Mason Value

Lindner

Mass. Investors

Mass. Investors Growth Stock

Merrill Lynch Balanced B

Merrill Lynch Basic Value A

Merrill Lynch Basic Value B

Merrill Lynch Capital A

Merrill Lynch Capital B

Merrill Lynch Growth B

Mutual Qualified

Mutual Shares

Neuberger/Berman Guardian

Neuberger/Berman Partners

New Economy

Nicholas

Oppenheimer Equity-Income

Phoenix Balanced

Phoenix Growth

Pioneer

Pioneer II

Prudential Equity B

Putnam Fund for Growth/Inc. A

Putnam Investors

Putnam Option Income II

Putnam Voyager A

Scudder Capital Growth

Scudder Growth \& Income

Selected American Shares

Sequoia

T. Rowe Price Equity-Income

T. Rowe Price Growth Stock

T. Rowe Price Growth/Income

Thomson Growth B

TNE Growth

United Accumulative

United Income

United Vanguard

Vanguard/Morgan Growth

Vanguard US Growth

Washington Mutual Investors

Wellington

Windsor II 